\title{
The Poverty of Empiricism
}

\section{Jens Mende \\ University of the Witwatersrand, Johannesburg, South Africa.}

\author{
mendej@sebs.wits.ac.za
}

\begin{abstract}
Many researchers - and their advisors on research method - adopt a doctrine called empiricism, which claims that researchers may only use empirical methods. This restrictive doctrine impoverishes any academic discipline where it is dominant. The main reason is that a discipline only qualifies for the status of a science after it has progressed beyond empirical generalisations to explanatory theories; but although empirical methods are useful for discovering the former, they are inherently useless for creating the latter. So the empiricist doctrine retards scientific progress. Researchers should be aware of this danger, and research methodologists should attempt to counter it.
\end{abstract}

Keywords: Empiricism, Positivism, Research Methodology, research methods, empirical research, theoretical research

\section{Introduction}

There is a world of difference between the terms 'empirical' and 'empiricism'. The term 'empirical' refers to a battery of very useful research methods. The term 'empiricism' refers to a restrictive methodological doctrine which claims that researchers may only use empirical methods. The purpose of this paper is not to disparage empirical research methods, but to warn readers that the empiricist doctrine impoverishes any discipline where it is deeply entrenched (Gower, 1997, p10), and to suggest some avenues of counteraction.

The subsequent sections explain why the empiricist doctrine impoverishes research. The first section shows that researchers need knowledge of various kinds of research processes and knowledge products, and that this knowledge is distributed over three academic disciplines: Philosophy of Science, History of Science and Research Methodology. The next three sections examine the origin and current status of the empiricist doctrine in the Philosophy of Science, and the debilitating effect of empiricism on research process and product knowledge in the History of Science and in Research Methodology. The last section calls for counter-action in the form of meta-research aimed at identifying non-empirical research processes and knowledge products that could be

Material published as part of this journal, either online or in print, is copyrighted by the publisher of Informing Science. Permission to make digital or paper copy of part or all of these works for personal or classroom use is granted without fee provided that the copies are not made or distributed for profit or commercial advantage AND that copies 1) bear this notice in full and 2) give the full citation on the first page. It is permissible to abstract these works so long as credit is given. To copy in all other cases or to republish or to post on a server or to redistribute to lists requires specific permission and payment of a fee. Contact Editor@inform.nu to request redistribution permission. mentioned in those three disciplines especially in Research Methodology.

As the argument in those sections is lengthy, no space is left over for detailed analysis of the impact of the empiricist doctrine on the Information Systems discipline, nor on any of the other disciplines under the umbrella of Informing Science. Readers are invited to judge by themselves, from 
their personal experience, whether those disciplines are dominated by the empiricist doctrine, and whether that doctrine has impoverished them.

\section{Methodological Knowledge}

Research is a process of producing new knowledge. So it is a productive process similar to the productive processes of manufacturing cars, computers, software, etc. Some useful insights emerge by analysing the other productive processes and then comparing them with the research process.

All productive processes require productive knowledge. For example:

- in order to produce cars, people need knowledge of car production;

- in order to produce computers, they need knowledge of computer production;

- in order to produce software, they need knowledge of software production.

Productive knowledge consists of process knowledge as well as product knowledge (see Mende, 2000 for more detail). When manufacturers establish a new factory, they have to decide what the factory is to produce, and how the factory will produce it. So they need to know what kinds of manufactured products are needed, and what kinds of processes can be used to produce them. For example, when Henry Ford decided to produce motor cars, he had to know that people need cars, and that cars can be produced on a production line.

Similarly, when researchers embark on a research project, they have to decide what knowledge product to produce and how to produce it. So they too need to know what kinds of knowledge products are required and what kinds of research processes can be used (Kantorovich, 1993, p11; Singleton, Straits \& Straits, 1993, p18). For example, when Ohm embarked on his famous research project to find the empirical law of electric current variation with voltage, he had to be aware that people need empirical laws, and that empirical laws can be produced by means of inductive research processes. Similarly, when Darwin embarked on his famous research project on the theory of evolution, he had to be aware that people need theories, and that theories can be established by means of deductive research processes.

Therefore, by analogy with manufacturing management, researchers need knowledge of different types of research processes and knowledge products. Since this is knowledge about knowledge, it may be called 'meta-knowledge'. For convenience of access, all our meta-knowledge should be concentrated in a single academic discipline. But that is not so. Instead, our meta-knowledge is scattered across three different disciplines, namely History of Science, Philosophy of Science and Research Methodology.

History of Science is an old-established discipline, which began with the ancient Greeks (Lloyd, 1973). Today, it describes many of the knowledge products that were discovered by real-life researchers, and also some of the research processes that those researchers actually used.

Philosophy of Science is another old-established discipline, which also began with the ancient Greeks. Today, it mainly analyses the validity of existing knowledge products, but occasionally considers the research processes too. Unfortunately, many publications in Philosophy of Science make scant reference to History of Science, and most of them ignore Research Methodology altogether.

Research Methodology is an emerging new discipline that aims to unify many of the methodological principles found in the various sciences and proto-sciences. During the latter half of the $20^{\text {th }}$ century, specialised methodological branches have emerged in many of those disciplines to focus on issues of method. For example, in the natural sciences there are textbooks on experimen- 
tal techniques of physics and chemistry, and on microscope techniques in biology and geology (Furniss, Hannaford, Smith, \& Tatchell, 1989; Heinrich, 1965; Sanderson, 1994). In the social proto-sciences there are textbooks on experimental psychology, sociological method, anthropological research, educational research and business research (Cassell \& Symon, 1994; Christensen, 1980; Cole, 1980; Foskett, 1965; Pelto \& Pelto, 1978; Zikmund, 2003). Yet certain methods are common to many of these disciplines.

"The research procedures of most academic disciplines follow the dictates of the scientific method ... In many instances, only the tools of research are different. The biologist gathers data by way of the microscope, the sociologist does likewise through a questionnaire. From there on the basic procedure of each is the same: to process the data, interpret them, and reach a conclusion based on factual evidence." (Leedy, 1989, p. vii).

The new discipline of Research Methodology identifies and explains these common research procedures. Unfortunately, most publications in Research Metholology make scant reference to Philosophy of Science and History of Science.

The three disciplines are subject to the force of fashion (Lovelock, 1995, p. 204; Nagel, 1961, p. 115; Sperber, 1990). This force arises in any social group, including a community of scholars. A scholar in an academic discipline is subject to research fashions in the same way as anyone else is subject to clothing fashions, motorcar fashions, food fashions, etc. The next three sections focus on the empiricist fashion. It originated in the Philosophy of Science, where it is now dismissed with contempt; but has spread to History of Science, where it is still mildly influential, and to Research Methodology, where it remains dangerously dominant.

\section{Philosophy of Science}

The precursor of empiricism was a philosophical doctrine called positivism. This was a doctrine of neglect. It called for neglect of a particular class of knowledge products, namely theories, and especially those theories that involve un-observable first causes (Oldroyd, 1986, p. 169). Positivism originated in the $18^{\text {th }}$ century, when Berkeley denied the reality of theoretical objects such as the Newtonian forces of mechanics (Losee, 1993, p. 168). Positivism was subsequently disseminated by two influential $19^{\text {th }}$ century philosopher-scientists: the sociologist Comte, who asserted that 'science must study only the laws of phenomena', and the physicist Mach, who attempted to purge all theoretical terms from Mechanics (Losee, 1993, p. 170; Whewell, 1860, p. 183). Positivism was disseminated even more widely in the early $20^{\text {th }}$ century, by a group of philosophers called the Vienna Circle, who regarded theoretical objects as meaningless, and a theory as a mere computational device for describing and predicting phenomena (Harre, 1960, p. 46; Hollis, 1994, p. 42).

Empiricism (or inductivism) is the logical consequence of positivism for research processes. In the same way as positivism dismisses theory, the doctrine of empiricism dismisses deductive theoretical methods, and demands that researchers should restrict themselves to inductive empirical methods.

"induction ... is the method proposed by crude empiricism to distinguish scientific inquiry

from non-scientific speculation" (Doyal \& Harris, 1986, pp. 2-3).

The remainder of this section demonstrates that the positivist and empiricist doctrines are dangerously restrictive. These doctrines fail first to an inductive empirical argument, and then to a deductive explanatory argument. 
The inductive argument is based on evidence from the History of Science, namely the many instances where empirical methods produced significantly less useful knowledge products than theoretical methods.

- Empirical methods merely enabled Galileo to discover the law of falling, whereas theoretical methods enabled Newton to discover the theory of Mechanics.

- Empirical methods merely enabled Ohm to discover the law of electrical resistance, whereas theoretical methods enabled Maxwell to discover the theory of electrodynamics.

- Empirical methods merely enabled Proust to discover the law of constant proportions in chemical reactions, whereas theoretical methods enabled Dalton to discover the atomic theory of chemistry.

- Empirical methods merely enabled Darwin to discover new biological species, whereas theoretical methods enabled him to discover the theory of biological evolution.

- etc., etc.

So, empirical methods were often less useful than theoretical methods. Now if today's researchers were trapped into empiricism, they would be restricted to empirical methods, and would be unable to produce the more useful theories. Therefore empiricism would impoverish research.

The deductive argument against the positivist empiricist doctrines is based on two propositions of the modern Philosophy of Science:

1. A true science has an explanatory theory that is organised as a deductive system.

2. Empirical methods are inappropriate for creating explanatory theories.

Proposition 1 means that an academic discipline does not qualify for the status of a science until it has progressed beyond empirical generalizations to explanatory theories. For example, the branches of Physics and Astronomy now called Dynamics and Celestial Mechanics were labelled 'natural philosophy' at the time Galileo formulated his empirical laws of motion and Kepler formulated his empirical laws of planetary orbits. They only achieved the status of sciences after Newton devised a deductive theory to explain Galileo's laws and Kepler's laws (Toulmin, 1953, p. 50). The first proposition is supported by the quotes in Table 1.

Table 1. The need for explanatory theories and deductive systems

\begin{tabular}{|c|c|}
\hline Source & Quote \\
\hline Copi, 1979 & $\begin{array}{l}\text { "No mere list or catalog of truths is ever said to constitute a system of } \\
\text { knowledge or a science. We have scientific knowledge only when the } \\
\text { propositions setting forth what we know are organized in a systematic } \\
\text { way, to display their inter-relations ... one important relationship } \\
\text { among the propositions of a science is deducibility. Propositions that } \\
\text { embody knowledge about a subject become a science of that subject } \\
\text { when they are arranged or ordered by displaying some of them as con- } \\
\text { clusions deduced from others" (p157). }\end{array}$ \\
\hline $\begin{array}{l}\text { Campbell, } \\
\text { N. R., } 1920\end{array}$ & $\begin{array}{l}\text { "the more purely phenomenal a proposition is and the less the element } \\
\text { of theory associated with it, the less is its certainty ... For why do we } \\
\text { call some laws "empirical' and associate with that term a slight ele- } \\
\text { ment of distrust? Because such laws are not explained by any theory" } \\
\text { (p153). }\end{array}$ \\
\hline
\end{tabular}




\begin{tabular}{|c|c|}
\hline arre, 1960 & $\begin{array}{l}\text { "it has been one of the fundamental aims of science to reach deductive } \\
\text { systems of knowledge" (p39). }\end{array}$ \\
\hline $\begin{array}{l}\text { Harre \& } \\
\text { Secord, } 1972\end{array}$ & $\begin{array}{l}\text { "The experimental work of Hooke and Boyle by which they estab- } \\
\text { lished the empirical patterns in the behaviour of confined samples of } \\
\text { gas that we express as PV }=\mathrm{K} \ldots \text { was proto-scientific. We do not } \\
\text { have real science until we know why P varies inversely as V, knowl- } \\
\text { edge which became available only after the molecular theory of gases } \\
\text { was formulated to provide us with an idea of the causal mechanism by } \\
\text { which this pattern was produced ... Science proper starts when the } \\
\text { question 'Why?' is put and theory develops to answer it." (p130-1). }\end{array}$ \\
\hline $\begin{array}{l}\text { Kantorovich, } \\
1993\end{array}$ & $\begin{array}{l}\text { "theory is one of the distinguishing characteristics of modern science" } \\
\text { (p16). }\end{array}$ \\
\hline Klee, 1997 & "explanation [is] the main business of science" (p4). \\
\hline $\begin{array}{l}\text { Mason \& } \\
\text { Bramble, } 1978\end{array}$ & $\begin{array}{l}\text { "the purpose of science is to develop theory, which can be defined as a } \\
\text { set of formulations designed to explain and predict phenomena" (p3). }\end{array}$ \\
\hline Phillips, 1985 & $\begin{array}{l}\text { "One goal of the scientific method is explanation: a theory as to the } \\
\text { causes and/or effects surrounding a given phenomenon" (p10). }\end{array}$ \\
\hline $\begin{array}{l}\text { McBurney, } \\
1994\end{array}$ & $\begin{array}{l}\text { "The ultimate goal of a science is the development of a theory to ex- } \\
\text { plain the lawful relationships that exist in a particular field" (p40). }\end{array}$ \\
\hline
\end{tabular}

Proposition 2, which asserts that empirical methods are inappropriate for creating explanatory theories, follows from the fact that empirical research involves inductive reasoning, whereas theoretical research involves deductive reasoning. Empirical methods induce generalisations from facts. Theoretical methods then explain the empirical generalisations by generating deductive arguments to the generalizations from first causes, which are usually un-observable. So inductive methods are useless for devising deductive explanatory theories.

This proposition is easy to confirm from cases in the History of Science. For instance, Newton made no observations or experiments, and analysed no data in devising the theory of Mechanics; neither did Dalton in devising the atomic theory of Chemistry, nor Darwin in devising the biological theory of evolution, nor Einstein in devising the relativity theory.

Table 2 provides further support from other authors.

Table 2. Inadequacy of empirical methods for creating explanatory theories

\begin{tabular}{|ll|}
\hline Source & Quote \\
\hline $\begin{array}{l}\text { Timasheff, } \\
1957\end{array}$ & $\begin{array}{l}\text { "Theory cannot be derived from observation and generalizations } \\
\text { merely by means of rigorous induction". } \\
\text { "a theory cannot be an empirical generalization from observational } \\
\text { data" (p85). }\end{array}$ \\
Koestler, 1969 & $\begin{array}{l}\text { "on Einstein's own testimony the Michelson-Morley experiment 'had } \\
\text { no role in the foundation of the theory' ... [It] was laid on theoreti- } \\
\text { cal, indeed speculative, considerations" (p243-4). } \\
\text { "But what about the method by which we obtain our theories or hy- } \\
\text { potheses? ... I do not believe that we ever make inductive generaliza- } \\
\text { tions in the sense that we start with observations and try to derive our } \\
\text { theories from them" (p19). }\end{array}$
\end{tabular}




\begin{tabular}{|ll|}
\hline Hughes, 1990 & "All the 'facts' Darwin used as evidence for his theory of evolution \\
& were known before he used them ... What Darwin contributed was a \\
& profoundly radical way of rearranging these materials" (p38). \\
Kantorovich, & "Inductive inference can generate empirical generalizations, but not \\
& explanatory theories ... Newton's theory of universal gravitation \\
& cannot be inductively inferred from the data on planetary motion and \\
& even not from Kepler's laws ...inductive generalization cannot lead \\
& from the data on gas behaviour, or from the empirical gas laws, to the \\
& kinetic theory of gases" (p66).
\end{tabular}

The positivist and empiricist doctrines now fail to a simple reductio ad absurdum.

Science is characterised by the existence of deductive explanatory theory.

Yet inductive empirical methods are inappropriate for creating deductive explanatory theory.

So inductive empirical methods are unlikely to produce a science.

The empiricist doctrine restricts researchers to inductive empirical methods.

So it impoverishes research by inhibiting progression to scientific status.

Yet the aim of this doctrine is to ensure scientific status.

Therefore empiricism is absurd.

So empiricism is untenable in the Philosophy of Science. Indeed, some philosophers have rejected the absurd empiricist doctrine in the past, and many others reject it today - see table 3.

Table 3. Criticisms of Empiricism

\begin{tabular}{|c|c|}
\hline Source & Quote \\
\hline Bacon, 1620 & $\begin{array}{l}\text { "The Empiric school produces dogmas of a more deformed and mon- } \\
\text { strous nature than the Sophistic or theoretic school (p29). }\end{array}$ \\
\hline \multirow[t]{2}{*}{ Bunge, 1967} & $\begin{array}{l}\text { "Empirical induction, i.e. generalization of observed cases, has been } \\
\text { grossly overestimated by philosophers who have concentrated on the } \\
\text { early (pretheoretical) stages of research" (p244). }\end{array}$ \\
\hline & $\begin{array}{l}\text { "The [extent] of theoretical work measures then the degree of ad- } \\
\text { vancement of a science ... This is why psychology and sociology, de- } \\
\text { spite their huge store of empirical data and low-level generalizations, } \\
\text { are regarded as being still in an underdeveloped stage: because they do } \\
\text { not abound with theories wide and deep enough to account for the } \\
\text { available empirical material. Yet in these as well as in other underde- } \\
\text { veloped departments of inquiry theorizing is frequently regarded as a } \\
\text { luxury and data gathering - i.e. description - as the only decent occu- } \\
\text { pation, to the point that theory (speculation) is opposed to research } \\
\text { (data hunting). This paleoscientific attitude, encouraged by a primitive } \\
\text { kind of empiricist philosophy, is largely responsible for the backward- } \\
\text { ness of the sciences of man" (p382). }\end{array}$ \\
\hline $\begin{array}{l}\text { Harre \& } \\
\text { Secord, } 1972\end{array}$ & $\begin{array}{l}\text { "A philosopher is often put in mind of the analogy to alchemy, where } \\
\text { an enormous amount of empirical and experimental work was done, } \\
\text { some of which was later incorporated into real chemistry, but most of } \\
\text { which was vitiated because of an inadequate conceptual basis" (p3). }\end{array}$ \\
\hline
\end{tabular}




\begin{tabular}{|c|c|}
\hline Gould, 1979 & $\begin{array}{l}\text { "Great scientists ... are distinguished more by their powers of hunch } \\
\text { and synthesis than by their skill in experiment and observation". }\end{array}$ \\
\hline $\begin{array}{l}\text { Wartofsky, } \\
1979\end{array}$ & $\begin{array}{l}\text { "early positivism, and its modifications in ... empiricism have failed" } \\
\text { (p27) }\end{array}$ \\
\hline Chalmers, 1982 & $\begin{array}{l}\text { "I regard the naïve inductivist account of science to be very wrong and } \\
\text { dangerously misleading" (p11). }\end{array}$ \\
\hline $\begin{array}{l}\text { Doyal \& } \\
\text { Harris, } 1986\end{array}$ & $\begin{array}{l}\text { "Traditional ideas about scientific method have been the target of } \\
\text { much recent criticism. This has been directed particularly against em- } \\
\text { piricism ... The critics of empiricism claim that it never was and never } \\
\text { could be the method of science and that the conscious or even uncon- } \\
\text { scious adherence to its principles could retard progressive scientific } \\
\text { discovery" (p1). }\end{array}$ \\
\hline Hull, 1988 & $\begin{array}{l}\text { "I had become increasingly dissatisfied through the years with the } \\
\text { logical empiricist analysis of science that had been so popular for over } \\
\text { a generation (xi). }\end{array}$ \\
\hline Laudan, 1996 & $\begin{array}{l}\text { "the positivists had mistaken ideas both about the agenda for philoso- } \\
\text { phy and about the solutions to certain prominent problems (p3). }\end{array}$ \\
\hline Azevedo, 1997 & $\begin{array}{l}\text { "Current adherents to positivism and empiricism are considered igno- } \\
\text { rant and behind the times" (p258). }\end{array}$ \\
\hline
\end{tabular}

Nevertheless, empiricism still influences the other two disciplines that are concerned with research method.

\section{History of Science}

Historians of Science are subject to the force of fashion - particularly by fashions in the Philosophy of Science.

"The historiography of science, more than the history of other aspects of human thought, is peculiarly subject to philosophic fashion" (Hesse, 1980, p. 3).

Many older historians have been influenced by the old empiricist philosophy (Hesse, 1980, p. 4; Hollis, 1994, p. 42). So when they decide which processes and products to study, they are likely to over-emphasise empirical processes and products, and neglect theoretical processes and products (Hesse, 1980. p. 5). Therefore, historians may have missed potentially useful research products and processes.

\section{Research Methodology}

The authors of Research Metholology textbooks are also subject to the force of fashion. They have been influenced by two fashions, namely scientism and empiricism.

Scientism was a pervasive research fashion until a few decades ago. According to this fashion, all scientists ought to emulate the 'empirical-analytical' method, which was supposedly used by many natural scientists, particularly physicists.

"The empirical-analytical method is the only valid approach to improve human knowledge. What cannot be investigated by it, cannot be investigated scientifically at all and therefore must be banned from the domain of science as unresearchable and consequently as unpublishable, unfundable and almost as unspeakable" (Klein \& Lyttinen, 1985). 
Empiricism is the pervasive research fashion today ... see Table 4.

Table 4 . The popularity of positivist empiricism

\begin{tabular}{|c|c|}
\hline Source & Quote \\
\hline $\begin{array}{l}\text { Von Bertalanffy, } \\
1968\end{array}$ & $\begin{array}{l}\text { "Only collection of data and experiments were considered as being } \\
\text { scientific in biology (and psychology); theory was equated with } \\
\text { speculation or philosophy, forgetting that a mere accumulation of } \\
\text { data, although steadily piling up, does not make a science" (p100). }\end{array}$ \\
\hline $\begin{array}{l}\text { Harre \& Secord, } \\
1972\end{array}$ & $\begin{array}{l}\text { "most psychologists have adopted a logical positivist metaphysics } \\
\text { and the methodology that goes with it" (p32). }\end{array}$ \\
\hline Easthope, 1974 & $\begin{array}{l}\text { "the tool - the scientific method - began to determine sociological } \\
\text { aims" (p139). }\end{array}$ \\
\hline $\begin{array}{l}\text { Doyal \& Harris, } \\
1986\end{array}$ & $\begin{array}{l}\text { "Empiricism in its crudest form is probably the epistemology which } \\
\text { is most generally accepted by people without philosophical training" } \\
\text { (p2). }\end{array}$ \\
\hline $\begin{array}{l}\text { Miller, R. W. } \\
1987\end{array}$ & $\begin{array}{l}\text { "At least as a working hypothesis, positivism is the most common } \\
\text { philosophical outlook on science" (p4). }\end{array}$ \\
\hline Hughes, 1990 & $\begin{array}{l}\text { "I refer to positivism as the orthodoxy because, in some of its ver- } \\
\text { sions, it is the philosophical epistemology that currently holds intel- } \\
\text { lectual sway within the domain of the social sciences" (p16). }\end{array}$ \\
\hline Azevedo, 1997 & $\begin{array}{l}\text { "For the greater part of this century [positivism] was the dominant } \\
\text { philosophy of science and it has been influential in sociology since } \\
\text { the discipline was first developed ... while positivism is no longer } \\
\text { dominant in the philosophy of science, it still dominates sociology, at } \\
\text { least in the United States" (p14+41). }\end{array}$ \\
\hline Gower, 1997 & $\begin{array}{l}\text { "The traditional accounts of scientific method, then, offer a logic of } \\
\text { science which is biased ... heavily in favour of an empiricist episte- } \\
\text { mology and ontology" (p259) }\end{array}$ \\
\hline
\end{tabular}

The empiricist doctrine is reflected in most of the textbooks of Research Methodology that were published during the past four decades. Their authors insist that research should invariably, or normally, involve data collection (by observation, experiment, document study, etc.), and data analysis (by inductive statistical and/or interpretive methods).

The authors rarely state these norms explicitly, but rather let their readers infer them implicitly. They do that in three ways.

First, some authors simply define 'research' as a process of data collection and data analysis (e.g. Bailey, 1987, p. 11; Creswell, 1994, p. xvii; Erlandson, Harris, Skipper, \& Allen, 1993, p. xvii; Leedy, 1989, p. 9; Miller, D. C., 1970, p. v; Neale \& Liebert, 1986, p. 7; Riley, 1963, p. xiv; Tuckman, 1978, p. 12-14; Williamson, Karp, Dalphin \& Gray, 1982, p. 4).

Second, other authors define 'the scientific method' as a process of data collection and data analysis (e.g. Bynner \& Stribley, 1978, p. 4-8; Heiman, 1995, pp. 9, 19; Kerlinger, 1986, pp. 1013; Labovitz \& Hagedorn, 1976, p. 23; Leedy, 1989, p. 80; Lehmann \& Mehrens, 1979, p. 3; Mason \& Bramble, 1978, p. 26; McMillan \& Schumacher, 1997, p. 9; Neuman, 1994, p. 8-11; Rummel, 1964, p. 11-15; Williamson et al., 1982, pp. 6-8).

Third, others define the 'hypothetico-deductive method' as hypothesis deduction from theory followed by data collection and analysis, and recommend this method as the model of research in 
any science (e.g. Bailey, 1987, p. 39; McNeill, 1985, p. 42; Sekaran, 1992, p. 16, TerreBlanche \& Durrheim, 1999, p. 4).

So the textbooks of Research Metholology either implicitly adopt the empiricist doctrine, by excluding all research methods other than the empirical methods, or explicitly adopt the empiricist doctrine, by suggesting that empiricism is necessary for an academic discipline to achieve scientific status. Examples are shown in Table 5.

Table 5. Empiricism in textbooks of Research Methods

\begin{tabular}{|c|c|}
\hline Authors & Quotes \\
\hline Turney \& Robb, 1971 & $\begin{array}{l}\text { "in [using] the scientific method .. the investigator ... collects, } \\
\text { organizes, tabulates, and analyses his data" (p4). }\end{array}$ \\
\hline Tuckman, 1978 & $\begin{array}{l}\text { "Characteristics of the research process. Research is empiri- } \\
\text { cal" (p10-11). }\end{array}$ \\
\hline $\begin{array}{l}\text { Williamson, et al. } \\
1982\end{array}$ & $\begin{array}{l}\text { "Systematic research in any field of inquiry involves two basic } \\
\text { operations... data collection [and] data analysis" (p4). }\end{array}$ \\
\hline Phillips, 1985 & "we must proceed to collect data [and] analyze data" (xi) \\
\hline Kerlinger, 1986 & "scientific investigation is empirical" (p11). \\
\hline Bailey, 1987 & $\begin{array}{l}\text { "Each research project entails gathering data, analyzing data } \\
\text { and interpreting data" (p11). }\end{array}$ \\
\hline Erlandson et al., 1993 & $\begin{array}{l}\text { "we hope they find in this book a way of collecting, analyzing } \\
\text { and reporting data" (xvii). }\end{array}$ \\
\hline Singleton et al., 1993 & $\begin{array}{l}\text { "the foremost characteristic of scientific inquiry is that it is } \\
\text { based on empiricism" (p30). }\end{array}$ \\
\hline McBurney, 1994 & "Empiricism is an essential characteristic of science" (p7). \\
\hline $\begin{array}{l}\text { Cooper \& Emory, } \\
1995\end{array}$ & "This book is concerned with empiricism" (p23). \\
\hline $\begin{array}{l}\text { McMillan \& } \\
\text { Schumacher, } 1997\end{array}$ & $\begin{array}{l}\text { "Research is characterized by a strong empirical attitude and } \\
\text { approach ..." (p12). }\end{array}$ \\
\hline
\end{tabular}

There are at least three reasons why positivism and empiricism are popular among researchers and their methodological advisors. One reason is that

“Today's science teaching reflects yesterday's philosophy of science" (Kantorovich, 1993, p. 255).

Another reason is that many research advisors know a great deal about confirming and falsifying theories, but know next to nothing about creating them (Phillips, 1985, p. 8). Furthermore, they seem to be unaware that their (physicist) role-models used not only inductive empirical methods of confirmation but also used deductive methods of discovery (Chalmers, 1982, pp. xv-xvi). So when authors write textbooks of Research Methodology, they would have no option but to emphasise the well-known empirical methods, and neglect the little-known theoretical methods. Similarly, some authors may neglect theoretical methods because they are unaware of the deductive-explanatory role of theory (e.g. Breakwell, Hammond \& Fife-Shaw, 1995, p. 5; Bynner \& Stribley, 1978, pp. 4-9; Erlandson et al. 1993, p. 16, 50; Kerlinger, 1986, p. 9; Labovitz \& Hagedorn, 1976, pp. 14-18; Leedy, 1989, p. 7; Mason \& Bramble, 1978, p. 53; McNeill, 1985, p. 176; Mouton \& Marais, 1990, p. 143; McMillan \& Schumacher, 1997, p. 8; Neuman, 1994, pp. 41-43; 
Sekaran, 1992, p. 20, Singleton et al., 1993, p. 23; Riley, 1963, p. 9; Terre Blanche \& Durrheim, 1999, p. 404).

A third reason is that some researchers and their advisors have made a virtue of necessity. They confine themselves to empirical methods because theoretical methods have not yet been seen to succeed.

"A great many parts of physics are tied together with a strong interconnecting network of fundamental physical theory from which all other parts can be derived, so-called first principles. On the other hand we have fields ... where empiricism is the order of the day simply because there is no generally valid group of first principles from which to operate." (Siever, 1970, p. 23-4).

"In the early periods of developing a discipline from an applied field, initial efforts are usually directed more toward establishing empirical facts. Later, facts from separate studies can be synthesized and ultimately integrated into theories." (McMillan \& Schumacher, 1997, p. 22).

This explains why some authors, even though they are aware of deductive explanatory theory, nevertheless restrict their textbooks mainly or exclusively to empirical methods (e.g. Babbie,1989, p. 46; Heiman, 1995, p. 17; McBurney, 1994, p. 42; Miller, D. C., 1970, p. 9; Phillips, 1985, p. 11; Rosnow \& Rosenthal, 1996, p. 39; Singleton et al., 1993, p. 23; Williamson et al., 1982, p. 23).

Nevertheless, whatever the reason for conforming to the positivist-empiricist doctrine, that doctrine is absurd, and can therefore be harmful. It is likely to be harmful in at least two ways. First, if researchers are restricted to inductive empirical methods, they would be unable to produce deductive explanatory theories: so positivist empiricism would paralyse theoretical research. Second, positivist empiricism is likely to affect the methodological selection mechanism. In the many academic disciplines that are dominated by positivist empiricism, researchers will tend to reject any Research Metholology textbook that fails to conform to the dominant fashion. So the authors will be motivated to conform too. The conformist textbooks would then reinforce the dominant fashion among research students.

Several other authors have expressed additional concerns, shown in table 6.

Table 6. Objections to positivism and empiricism

\begin{tabular}{|ll|}
\hline Source & Quote \\
\hline $\begin{array}{l}\text { Harre \& Secord, } \\
1972\end{array}$ & "The need for ... a reformed methodology we feel to be pressing, \\
& and to be evident from the increasing dissatisfaction with the state \\
& of social psychology. The underlying reason for this state we be- \\
& lieve to be a continued adherence to a positivist methodology, long \\
& after the theoretical justification for it, in naïve behaviourism, has \\
& been repudiated" (p1). \\
& "what many psychologists and some other behavioural scientists \\
& are doing is overemphasizing empiricism at the expense of concep- \\
& tualization, or fact at the expense of ideas. They are acting as if ob- \\
& servation and experiment by themselves can create a science. This \\
& misplaced emphasis stems from an approach to science via logical \\
& positivism" (p36).
\end{tabular}




\begin{tabular}{|l} 
Chalmers, 1982 "Many areas of study are described as sciences by their supporters, \\
presumably in an effort to imply that the methods used are as \\
firmly based and as potentially fruitful as in a traditional science \\
such as physics. ... Self-avowed 'scientists' in such fields will of- \\
ten see themselves as following the empirical methods of physics, \\
which for them means the collection of 'facts' by means of careful \\
observation and experiment ... failing to realize that the method \\
they endeavour to follow is not only necessarily barren and unfruit- \\
ful but also is not the method to which the success of physics is to \\
be attributed." (xv-xvi). \\
"The desire of the abstracted empiricists to be scientific and their \\
belief that positivism provided the scientific method led them to \\
follow its prescriptions in a way never seen in the natural sciences, \\
even in physics, of which positivism was an attempted, if unsuc- \\
cessful model. They allowed 'the scientific method' to determine \\
the sort of problems they took up and the ways in which they were \\
formulated" (p15).
\end{tabular}

Research cultism. A research cult can form if a research fashion becomes self-perpetuating. Klein \& Lyttinen (1985) have explained how this can happen. Suppose a specific set of research processes and knowledge products has become fashionable in a particular discipline. Then research supervisors who adopt that fashion will insist that their students use the fashionable research processes to produce the fashionable knowledge products. When these students in turn become supervisors, they too will insist that their students use the fashionable processes to produce the fashionable products. And so on.

Cults are likely to form around positivist-empiricism:

"All those who do not abide by the precepts of empiricism are thus threatened with excommunication from the bosom of science" (Doyal \& Harris, 1986, p1).

Cults are particularly likely to form in academic disciplines that have not yet secured scientific status, which include the social 'sciences' and most other disciplines except the natural sciences.

"One of the livelier academic debates of recent years has concerned the scientific status of those disciplines gathered under the heading social sciences ... Academicians have disagreed about calling these disciplines sciences" (Babbie,1989 p30).

In these disciplines, an additional mechanism of cult formation is present. The leaders of these disciplines aspire to scientific status, but have not studied Philosophy of Science. So they are easily trapped by the positivist or empiricist doctrines. When that happens, it affects hiring and promotions, the funding of research projects, and the publication of research papers. Accordingly, subordinate researchers are obliged either to accept those doctrines too, or else give up a research career. So a vicious circle forms, and those doctrines can dominate the entire discipline within a few decades. For example,

- during the 1930's and 40's, a positivist cult probably formed in American Psychology. It was called behaviourism. Watson, Skinner, and their followers restricted psychological researchers to a program of naïve experimentalism, and repressed any attempt to use intervening variables in explaining human cognition (Cziko, 1995, p. 93; Gardner, 1985, p. 109; Harre \& Secord, 1972, p. 136; Hothersall, 1990, p. 405).

- during the 1980's, an empiricist cult may have formed in Information Systems. American $\mathrm{PhD}$ supervisors restricted graduate students to a range of methods that were unable to answer questions of systems effectiveness (Klein \& Lyttinen, 1985; Nissen, 1985). And fund- 
ing committees imposed the same restrictions on researchers (Fitzgerald, Hirshheim, Mumford \& Wood-Harper, 1985).

Positivist-empiricist cultism would intensify the harmful effects identified earlier. These cults would be dangerously restrictive, confining researchers to a narrow range of processes and products (Bauer, 1992, p. 75; Harre, 1981; Lovelock, 1995, p. xvii; Whitley, 1984, p. 146). In particular, they would paralyse theoretical research, and that would - ironically - prevent an academic discipline from achieving scientific status. The failure to achieve scientific status may then step up the vicious circle. Academic leaders would attribute the failure to insufficiency of empirical research, and increase their efforts to eliminate non-empirical research. As a result, empiricist cultism can retard progress for decades - as happened in Psychology sixty years ago, and as may be happening in Information Systems today.

Positivist and empiricist cultism are also likely to affect the methodological selection mechanism. For instance, if an academic discipline is dominated by an empiricist cult, then researchers would be strongly discouraged from doing any non-empirical work, and would avoid buying any Research Metholology books that do not conform to the ruling empiricist doctrine. So when methodologists write metholology textbooks, or teach metholology courses, they would be totally rejected unless they conform to the empiricist mould. Therefore, if many academic disciplines are dominated by empiricist cults, the demand for non-empiricist Research Metholology books would shrink to extinction, and publishers would avoid such books. This would account for the flood of empiricist textbooks of Research Metholology that is reaching the bookshops today.

In summary, then, the emerging discipline of Research Methodology is facing some very serious problems. Methodologists may be inhibited by research fashions. They are probably inhibited by the empiricist fashion (or even cult), which is likely to paralyse theoretical research. As a result, methodologists have probably missed many useful research processes and knowledge products.

Content analysis. This suspicion was confirmed by analysing a sample of Research Metholology textbooks whose authors appear to have minimum bias towards positivist empiricism. Table 7 identifies the actual research processes mentioned in these textbooks, and lists them in empirical and non-empirical columns.

Table 7. Content Analysis of Research Metholology textbooks

\begin{tabular}{|c|c|c|}
\hline Authors & Empirical Research Processes & Non-Empirical \\
\hline Riley, 1963 & $\begin{array}{l}\text { Experiment (21), document study (21), observation } \\
(22) \text {, questioning (22), participant observation \& } \\
\text { questioning (22), qualitative description (22), meas- } \\
\text { urement (23), sampling (283), measurement (328), } \\
\text { statistical analysis (404), trend study (550), experi- } \\
\text { ment (612). }\end{array}$ & $\begin{array}{l}\text { Theory extension } \\
(27) \text {, hypothesis } \\
\text { deduction from } \\
\text { theory (28). }\end{array}$ \\
\hline Rummel, 1964 & $\begin{array}{l}\text { Sampling (66), observation (84), interview (99), } \\
\text { document analysis (163), experimental design (178), } \\
\text { scaling (198). }\end{array}$ & \\
\hline $\begin{array}{l}\text { Williamson et al., } \\
1982\end{array}$ & $\begin{array}{l}\text { Measurement (63), sampling (103), survey (125), } \\
\text { interview (163), participant observation (192), ex- } \\
\text { periment (214), historical analysis (239), content } \\
\text { analysis (260), aggregate analysis (260), statistical } \\
\text { analysis (377). }\end{array}$ & \\
\hline
\end{tabular}




\begin{tabular}{|c|c|c|}
\hline Phillips, 1985 & $\begin{array}{l}\text { Measurement (107), sampling (175), survey (211), } \\
\text { observation (291), experiment (323), simulation } \\
(353) \text {, cross tabulation (419), statistical analysis } \\
(471) \text {. }\end{array}$ & \\
\hline $\begin{array}{l}\text { Neale \& Liebert, } \\
1986\end{array}$ & $\begin{array}{l}\text { Case history (26), sampling (31), measurement (34), } \\
\text { survey (49), Mill's methods (91), validity (98), ex- } \\
\text { perimental design (134), passive observation (227). }\end{array}$ & \\
\hline Bailey, 1987 & $\begin{array}{l}\text { Measurement (59), sampling (79), questionnaire } \\
\text { (104), interview (173), experimental design (213), } \\
\text { observation (238), document study (290), simulation } \\
\text { (317), statistical analysis (384). }\end{array}$ & $\begin{array}{l}\text { Deductive theory } \\
\text { construction (444). }\end{array}$ \\
\hline Babbie, 1989 & $\begin{array}{l}\text { Grounded theory construction (51), sampling (163), } \\
\text { experiment (211), survey (235), field observation } \\
(260) \text {, content analysis (293), secondary analysis } \\
(310), \text { historical analysis (317), statistical analysis } \\
(368+435) \text {. }\end{array}$ & $\begin{array}{l}\text { Hypothesis deduc- } \\
\text { tion from theory } \\
(39) \text {. }\end{array}$ \\
\hline Leedy, 1989 & $\begin{array}{l}\text { Historical analysis (125), questionnaire (142), inter- } \\
\text { view (148), sampling (151), analytic survey (174), } \\
\text { experiment (217). }\end{array}$ & \\
\hline Sekaran, 1992 & $\begin{array}{l}\text { Conceptual modelling (63), experimental design } \\
\text { (114), measurement (148), reliability \& validity } \\
(171) \text {, interview (190), questionnaire (200), sampling } \\
(223) \text {, statistical analysis (258). }\end{array}$ & $\begin{array}{l}\text { Hypothesis deduc- } \\
\text { tion from theory } \\
(79) \text {. }\end{array}$ \\
\hline $\begin{array}{l}\text { Singleton et al., } \\
1993\end{array}$ & $\begin{array}{l}\text { Measurement (100), sampling (136), experimental } \\
\text { design (179), survey (246), field observation (316), } \\
\text { using available data (354), historical analysis (373). }\end{array}$ & $\begin{array}{l}\text { Deductive reason- } \\
\text { ing (44). }\end{array}$ \\
\hline McBurney, 1994 & $\begin{array}{l}\text { Control (141), naturalistic observation (175), partici- } \\
\text { pant obser-vation (171), case study (179), question- } \\
\text { naire (194), sampling (202), experimental design } \\
(221) \text {, statistical nalysis (411). }\end{array}$ & \\
\hline $\begin{array}{l}\text { Breakwell et al., } \\
1995\end{array}$ & $\begin{array}{l}\text { Measurement (38), experimental design (50), survey } \\
\text { (99), sampling (104), facet analysis (116), question- } \\
\text { naire (174), direct observation (213), interview } \\
(230) \text {, discourse analysis (243), scalogram analysis } \\
(259) \text {, historical analysis (314), statistical analysis } \\
(338) \text {. }\end{array}$ & $\begin{array}{l}\text { Meta analysis } \\
(386) \text {. }\end{array}$ \\
\hline $\begin{array}{l}\text { Rosnow \& Rosen- } \\
\text { thal, } 1996\end{array}$ & $\begin{array}{l}\text { Measurement (94), reliability \& validity (121), ex- } \\
\text { perimental design (143), survey (188), statistical } \\
\text { analysis (213). }\end{array}$ & \\
\hline Elmes, et al., 1999 & $\begin{array}{l}\text { Measurement (187), experiment (256), complex ex- } \\
\text { periment (235), small-n experiment (259), quasi- } \\
\text { experiment (259), interpretation (299). }\end{array}$ & \\
\hline Zikmund, 2003 & $\begin{array}{l}\text { Qualitative analysis (109), survey (174), observation } \\
\text { (234), experiment (256), measurement (292), sam- } \\
\text { pling (368), data analysis (452). }\end{array}$ & $\begin{array}{l}\text { Theory building } \\
(40) \text {. }\end{array}$ \\
\hline
\end{tabular}

Note: The name 'grounded theory' does not actually refer to a deductive explanatory theory, but rather to a group of related empirical propositions. A more realistic name would be 'empirical model'. 
The Poverty of Empiricism

Table 7 has two implications. First, the non-empirical column has relatively few entries. So even though the textbooks were selected for minimum bias, each one actually has a very strong positivist/empiricist bias. Generalising from the sample, one would therefore expect that

most textbooks of Research Metholology are biased towards positivist empiricism.

Second, few such books provide any coverage of several important research processes that have been mentioned by philosophers and historians of science. For instance:

- Serendipity, to find a proposition about one type of object while studying another type of object (Bauer, 1992, pp. 87, 111, 118, 121; Boden, 1990. pp. 15, 49, 218; Bundy, 1997, p. 21; Campbell, D. T., 1974, pp. 427, 435; Chalmers, 1982, p. 34; Csikszentmihalyi, 1996, p. 196; Harre, 1985, p. 172; Kantorovich, 1993, pp. 3, 7, 101, 148-171, 154, 166, 180, 223; Miller, A. I., 1996, pp. 95, 374, 375; Popper, 1979, p. 108; Singleton et al., 1993, p. 29; Whewell, 1860, pp. 119-121; Wuketits, 1990, p. 164; Ziman, 1978, pp. 131, 139, 148).

- Conjecture, to guess a potential solution to a problem (Bauer, 1992, p. 45+111; Bundy, 1997, p. 22; Campbell, D. T. 1974, p. 427;Campbell, N. R., 1920, p. 225; Chalmers, 1982, p. 44; Einstein \& Infeld, 1938, p. 47; Gower, 1997, pp. 43, 118, 125; Harre, 1960, p. 175, 1970, pp. 39, 42, 46, 52; 1985, pp. 171, 180; Harre \& Secord, 1972, pp. 73, 76, 180; Hesse, 1974, pp. 89, 204; Hollis, 1994, p. 64; Hughes, 1990, pp. 61, 90; Kantorovich, 1993, pp. 39, 59, 61, 175; Koestler, 1969, p. 200; Losee, 1993, p. 121; Miller, A. I., 1996, pp. 79, 93, 97, 205, 337, 351, 369, 445; Newton-Smith, 1981, pp. 62, 211; Pantin, 1968, p. 121; Popper, 1979, pp. 31, 277; Ruse, 1998, p. 46; Thouless, 1953, p. 71+74; Whewell, 1860, pp. 133, 139-146, 174; Wilson, E. O., 1998, pp. 52-53; Ziman, 1978, pp. 22, 24, 30, 31, 88, 91, 101, $132,139)$.

- Thought experiment, to generate theoretical models by imagining a situation and then using its features as premises of an inductive or deductive argument (Azevedo, 1997, p. 56; Brown, 1992, p. 34; Gower, 1997, p. 31; Klee, 1997, p. 60; Miller, R. W., 1987, p. 63; Miller, A. I., 1996, pp. 7, 29, 109, 114, 128, 205, 258, 364, 375; Pratt, 1978, p. 87).

- Logical deduction, to explain observable empirical regularities from unobservable firstcauses (Azevedo, 1997, pp. 15, 41, 44, 157; Campbell, N. R., 1920, pp. 108, 116, 123, 128 , 146; Chalmers, 1982, p. 5; Doyal \& Harris, 1986, pp. 94, 96; Gower, 1997, pp. 37, 120, 194; Harre, 1970, p. 15, 1985, pp. 38, 54; Hollis, 1994, pp. 31, 62, 63; Hughes, 1990, pp. 51, 52; Kantorovich, 1993, pp. 28, 64, 66, 127; Klee, 1997, p. 107; Losee, 1993, p. 158; Miller, R. W., 1987, pp. 18, 40, 226; Miller, A. I., 1996, pp. 40, 205, 351, 403, 408; Nagel, 1961, pp. 21, 31, 65; Newton-Smith, 1981, p. 212; Pantin, 1968, p. 100; Popper, 1959, p. 32; Pratt, 1978, p. 84; Ruse, 1998, p. 150; Ryan, 1970, pp. 46, 49, 128, 199, 200; Whewell, 1860, pp. 137, 174, 193; Wilson, E. O., 1998, p. 28; Wuketits, 1990, p. 170; Ziman, 1978, pp. 18, 33, 140).

- Teleological methods, to identify human purposes and connect them to human actions (Doyal \& Harris, 1986, p. 52-63; Nagel, 1961, pp. 23-25, 401-428, 532-535, 411-418, $422-$ 424;.Ryan, 1970, p. 140)

Therefore methodologists have indeed omitted many useful research processes and knowledge products.

Consequently:

The impoverished empiricist textbooks of Research Metholology cannot qualify as comprehensive sources of research processes and knowledge products. 
Researchers who rely exclusively on those books are likely to find themselves in a methodological rut.

Academic research programs that refer students exclusively to those books may lead the next generation of researchers into a methodological rut.

\section{Research on Research}

The prevalence of empiricism casts serious doubts on the methodological recommendations of History of Science, and especially Research Methodology. So there is a need for corrective action.

When people seek practical advice on how to do research, they are more likely to select textbooks entitled 'Research Methods' than textbooks entitled 'Philosophy of Science' or 'History of Science'. They would be justified in doing so because, firstly, the title 'Research Methods' is more obviously relevant to the work of researchers, and secondly, because authors in Philosophy of Science and History of Science rarely aim to provide practical advice on how to do research. So the corrective action should mainly be aimed at the emerging discipline of Research Methodology.

Authors in this discipline could do several things.

- They could try to undermine empiricist cults. The obvious approach is to point out that empirical research alone cannot produce deductive explanatory theories, and is therefore likely to retard progress towards scientific status. A more devious approach would be to manipulate the fashion process. If academic opinion leaders want to retain their leadership positions, they should not be seen to support unfashionable policies (Sperber, 1990). So the leaders might well abandon positivist empiricism if they were to suspect that this doctrine was going out of fashion. That suspicion could perhaps be raised by drawing their attention to some of the criticisms of positivism and empiricism that were quoted above.

- They could try to transform Research Metholology into a science by producing an explanatory theory of research method.

- Most importantly, they could try to establish a comprehensive classification of needed knowledge products and a corresponding battery of research processes.

To establish the classification of products and the battery of processes, methodologists should not merely debate issues of research, but should practice what they preach, by doing research on research. Hundreds of research projects could be carried out to find new research processes and knowledge products. To begin, these projects could simply import existing processes and products from related disciplines.

- Several processes and products could be imported into Research Metholology from the History of Science (Phillips, $1985 \mathrm{p} 14$ ). The historians describe processes that scientists have actually used (e.g. Bowler, 1992; Brock, 1992; Cardwell, 1994; Mayr, 1982; Miller, 1996; North, 1994; Pais, 1982; Singer, 1959; Smith, 1997). In particular, they could look for nonempirical methods such as mathematical and logical deduction.

- Several processes and products could be imported from the Philosophy of Science. For instance, several authors have suggested taking advantage of analogies between the systems studied by different disciplines (Harre, 1960, 1970, 1985; Hesse, 1963, 1974; Nagel, 1961; Ryan, 1970). 
- Further processes could perhaps be imported from Cognitive Psychology. For instance, several authors have described human methods of problem solving and invention (De Bono, 1967-1992; Hadamard, 1945; Polya, 1954, 1957). The aim of most research projects is to solve a problem or a puzzle (Kuhn, 1970, pp. 139, 151, 161; Laudan, 1977; McBurney, 1994, p. 53). The solution often involves invention (Bronowski, 1973, p. 10; Harre, 1970, 1985; Hughes, 1990; Kantorovich, 1993; Ruse, 1998; Whewell, 1860; Ziman, 1978). Therefore these cognitive methods could be used for research purposes. As hybrids that include both empirical and non-empirical components, they enable a researcher to tackle a problem both ways.

- Further hybrids could perhaps be imported from Engineering and Management, which contain methods such as designing and planning (Brown, 1988; Drucker, 1985; Goldberg \& Sifonis, 1994; Peters, 1997; Pollard, 1974, 1978). These methods could be adapted for use in creating new knowledge.

- Further hybrids could probably be imported from Systems Theory. Methods such as systems analysis and modelling could be used in solving research problems (Blanchard \& Fabrycky, 1981; Checkland, 1981; Cleland \& King, 1975; Robertshaw, Mecca, \& Rerick, 1978; Schoderbek, Schoderbek, \& Kefalas, 1990; Troncale, 1988; Wilson, B. 1990). In particular, Von Bertalanffy (1968) has suggested that a special type of analogy called a homology can be used for knowledge transfer between different disciplines.

\section{Conclusion}

The previous sections have shown that the empiricist doctrine is dangerause, because it impoverishes research with its absurd claim that researchers should use empirical methods exclusively. In particular:

- researchers need knowledge of both the methods of research and the products of research, and this knowledge is available not only in textbooks of Research Metholology but also in the History of Science and the Philosophy of Science

- empirical research merely produces isolated empirical generalisations, whereas theoretical research integrates them into a comprehensive explanatory system, and as 'the whole is greater than the sum of the parts', a broad theory is more useful than a set of isolated generalizations

- inductive empirical research methods are not appropriate for producing deductive explanatory theories, and because the empiricist doctrine restricts its adherents to empirical methods, it confines them to producing the less-useful generalizations, and prevents them producing the more useful theories

- an academic discipline only qualifies for the status of a science when it has progressed beyond empirical generalizations to explanatory theories, and as the empiricist doctrine restricts its adherents to empirical methods, it prevents them from progressing to scientific status

- yet empiricism is firmly entrenched in many academic disciplines; so researchers should ask themselves 'have I been influenced by this doctrine, either wittingly or unwittingly?' - and if so, they should reject it vigorously!

Further work is necessary to assess the extent to which empiricism has entrenched itself in the Information Systems discipline - and still remains entrenched - as also in the other disciplines under the umbrella of Informing Science, and to assess the extent to which it has impoverished 
previous research - and is impoverishing current research. The present author's personal experience suggests that empiricism has strongly influenced the Information Systems discipline, although its influence is beginning to decline. So there is hope for the future. In particular, someone may soon break out of the inductive empiricist mould and devise a deductive theory of IS that explains the many empirical findings of the previous decades.

\section{References}

Azevedo, J. (1997). Mapping reality: An evolutionary realist methodology for the natural and social sciences. Albany, NY: State University of New York Press.

Babbie, E. (1989). The practice of social research. Belmont, California: Wadsworth.

Bacon, F. (1620). Novum organum. London: Routledge (reprint of 1893).

Bailey, K. D. (1987). Methods of social research. New York: Free Press.

Bauer, H. (1992). Scientific literacy and the myth of the scientific method. Urbana, Illinois: University of Illinois Press.

Blanchard, B. S. \& Fabrycky W. J. (1981). Systems engineering and analysis. Englewood Cliffs, NJ: Prentice-Hall.

Boden, M. (1990). The creative mind. London: Weidenfeld \& Nicolson.

Bowler, P. (1992). The Fontana history of the environmental sciences. London: Fontana.

Breakwell, G. M., Hammond S. \& Fife-Shaw C. (1995). Research methods in psychology. London: Sage.

Brock. W. H. (1992). The Fontana history of chemistry. London: Fontana.

Bronowski, J. (1973). The ascent of man. London: Macdonald.

Brown, J. R. (1992). The laboratory of the mind: Thought experiments in the natural sciences. London: Routledge.

Brown, K. A. (1988). Inventors at work. Washington: Tempus Books of Microsoft Press.

Bundy, W. M. (1997). The art of discovery. USA: Crisp.

Bunge, M. (1967). Scientific research I: The search for system. Berlin: Springer.

Bynner, J. \& Stribley, K. M. (1978). Social research: Principles and procedures. Harlow, Essex: Longman.

Campbell, D. T. (1974). Evolutionary epistemology. In P. A. Schilpp (Ed.), The philosophy of Karl Popper (pp.413-463). La Salle, Illinois: Open Court.

Campbell, N. R. (1920). Foundations of science: The philosophy of theory and experiment. New York: Dover (republished 1957).

Cardwell, D. (1994). The Fontana history of technology. London: Fontana.

Cassell, C. \& Symon G. (1994). Qualitative methods in organizational research. London: Sage.

Chalmers, A. F. (1982). What is this thing called science? Milton Keynes: Open University Press.

Checkland, P. (1981). Systems thinking, systems practice. Chichester: John Wiley.

Christensen, L. B. (1980). Experimental methodology. Boston: Allyn and Bacon.

Cleland, D. I. \& King, W. R. (1975). Systems analysis and project management. New York: McGraw-Hill.

Cole, S. (1980). The sociological method. Boston: Houghton Mifflin.

Cooper, D. R. \& Emory, C. W. (1995). Business research methods. Chicago: Irwin. 
The Poverty of Empiricism

Copi, I. M. (1979). Symbolic logic. New York: Macmillan.

Creswell, J. W. (1994). Research design: Qualitative and quantitative. London: Sage.

Csikszentmihalyi, M. (1996). Creativity: Flow and the psychology of discovery and invention. London: Harper Collins.

Cziko, G. (1995). Without miracles. Cambridge, Mass: MIT Press.

De Bono, E. (1967a). The 5-day course in thinking. New York: Basic Books.

De Bono, E. (1967b). The uses of lateral thinking. London: Jonathan Cape.

De Bono, E. (1970). Lateral thinking. Harmondsworth, Middlesex: Penguin.

De Bono, E. (1971). Lateral thinking for management. New York: McGraw-Hill.

De Bono, E. (1972). Po: Beyond yes and no. Harmondsworth, Middlesex: Penguin.

De Bono, E. (1982). De Bono's thinking course. London: BBC Books.

De Bono, E. (1982). Letters to thinkers. Harmondsworth, Middlesex: Penguin.

De Bono, E. (1985a). Six thinking hats. Harmondsworth, Middlesex: Penguin.

De Bono, E. (1985b). Tactics: The art and science of success. London: William Collins.

De Bono, E. (1992). Serious creativity. London: Harper Collins.

Doyal, L. \& Harris, R. (1986). Empiricism, explanation and rationality. London: Routledge \& Kegan Paul.

Drucker, P. F. (1985). Innovation and entrepreneurship. London: William Heinemann.

Easthope, G. (1974). A history of social research methods. London: Longman

Einstein, A. \& Infeld, L. (1938). The evolution of physics. New York: Simon and Schuster.

Elmes D G, Kantowitz, B H \& Roediger H L (1999). Research methods in psychology. Pacific Grove, Cal: Brooks/Cole.

Erlandson, D. A., Harris, E. L., Skipper, B. L. \& Allen, S. D. (1993). Doing naturalistic inquiry. London: Sage.

Fitzgerald, G., Hirshheim, R. A., Mumford, E. \& Wood-Harper, A. T. (1985). Information systems methodology. In E. Mumford, R. Hirschheim, G. Fitzgerald \& T. Wood-Harper (Eds.), Research methods in information systems (pp. 3-9). Amsterdam: North-Holland.

Foskett, D. J. (1965). How to find out: Educational research. Oxford: Pergamon.

Furniss, B. S., Hannaford, A. J., Smith, P. W. G. \& Tatchell, A. R. (1989). Vogel's textbook of practical organic chemistry. Harlow, Essex: Longman.

Gardner, H. (1985). The mind's new science - A history of the cognitive revolution. New York: Basic Books, p12.

Goldberg, B. \& Sifonis, J. G. (1994). Dynamic planning. Oxford: Oxford University Press.

Gould, S. J. (1979). Darwin's middle road. Natural History, 88 (12), p27-31. Reprinted in H. S. Horton; Thinking through writing (pp. 173-178). Baltimore: Johns Hopkins University Press.

Gower, B. (1997). Scientific method: An historical and philosophical introduction. London: Routledge.

Hadamard, J. (1945). The psychology of invention in the mathematical field. New York: Dover.

Harre, R. (1960). An introduction to the logic of the sciences. New York: Macmillan, p87, 91, 143, 162.

Harre R. (1970). The principles of scientific thinking. New York: Macmillan.

Harre, R. (1981). The positivist-empiricist approach and its alternative. In P. Reason \& J. Rowan (Eds.), Human inquiry (pp. 3-17). New York: John Wiley. 
Harre, R. (1985). The philosophies of science. Oxford: Oxford University Press.

Harre, R. \& Secord, P. F. (1972). The explanation of social behaviour. Oxford: Basil Blackwell.

Heiman, G. A. (1995). Research methods in psychology. Boston: Houghton Mifflin.

Heinrich, E. W. (1965). Microscopic identification of minerals. New York: McGraw-Hill.

Hesse, M. B. (1963). Models and analogies in science. London: Croom Helm.

Hesse, M. B. (1974). The structure of scientific inference. Los Angeles: University of California Press.

Hesse, M. B. (1980). Revolutions and reconstructions in the philosophy of science. Brighton Sussex: Harvester.

Hollis, M. (1994). The philosophy of social science. Cambridge: Cambridge University Press.

Hothersall, D. (1990). History of psychology. New York: McGraw-Hill, p431, 447.

Hughes, J. (1990). The philosophy of social research. Harlow, Essex: Longman.

Hull, D. L. (1988). Science as a process. Chicago: University of Chicago Press.

Kantorovich, A. (1993). Scientific discovery: Logic and tinkering. Albany, N Y: State University of New York Press.

Kerlinger, F. N. (1986). Foundations of behavioral research. New York: Holt, Rinehart and Winston.

Klee, R. (1997). Introduction to the philosophy of science. Oxford: Oxford University Press.

Klein, H. K. \& Lyttinen, K. (1985). The poverty of scientism in information systems. In E. Mumford, R. Hirschheim, G. Fitzgerald \& T. Wood-Harper (Eds.), Research methods in information systems (pp. 131-161). Amsterdam: North-Holland.

Koestler, A. (1969). The act of creation. London: Pan Books.

Kuhn, T. (1970). The structure of scientific revolutions. Chicago: University of Chicago Press.

Labovitz, S. \& Hagedorn, R. (1976). Introduction to social research. New York: McGraw-Hill.

Laudan, L. (1977). Progress and its problems. Berkeley, Cal: University of California Press.

Laudan, L. (1996). Beyond positivism and relativism. Boulder, Col: Westview Press.

Leedy, P. D. (1989). Practical research. New York: Macmillan.

Lehmann, I. J. \& Mehrens, W. A. (1979). Educational research. New York: Holt Rinehart Winston.

Lloyd, G. E. R. (1973). Greek Science: After Aristotle. New York: W. W. Norton.

Losee, J. (1993). A historical introduction to the philosophy of science. Oxford: Oxford University Press.

Lovelock, J. (1995). The ages of Gaia. Oxford: Oxford University Press.

Mason, E. J. \& Bramble, W. J. (1978). Understanding and conducting research. New York: McGraw-Hill.

Mayr, E. (1982). The growth of biological thought: Diversity, evolution and inheritance. Cambridge, Massachusetts: Harvard University Press.

McBurney, D. H. (1994). Research methods. Pacific Grove, Cal: Brooks/Cole.

McMillan, J. H. \& Schumacher, S. (1997). Research in education. Reading, Mass: Addison Wesley.

McNeill, P. (1985). Research methods. London: Tavistock.

Mende, J. (2000). Product and process alternatives in research. Accessible at http://www.isys.wits.ac.za, (updated in 2005).

Miller, A. I. (1996). Insights of genius: Imagery and creativity in science and art. Berlin: Springer-Verlag. 
The Poverty of Empiricism

Miller, D. C. (1970). Handbook of research design and social measurement. New York: David McKay.

Miller, R. W. (1987). Fact and method: Explanation, confirmation and reality in the natural and social sciences. Princeton, NJ: Princeton University Press.

Mouton, J. \& Marais, H. C. (1990). Basic concepts in the methodology of the social sciences. Pretoria: Human Sciences Research Council.

Nagel, E. (1961). The structure of science. London: Routledge \& Kegan Paul.

Neale, J. M. \& Liebert, R. M. (1986). Science and behavior: An introduction to methods of research Englewood Cliffs, NJ: Prentice-Hall.

Neuman, W. L. (1994). Social research methods. Boston: Allyn and Bacon.

Newton-Smith, W H (1981). The rationality of science. London: Routledge \& Kegan Paul.

Nissen, H-E. (1985). Acquiring knowledge of information systems - Research in a quagmire. In E. Mumford, R. Hirschheim, G. Fitzgerald \& T. Wood-Harper (Eds.), Research methods in information systems (pp. 39-51). Amsterdam: North-Holland.

North, J. (1994). The Fontana history of astronomy and cosmology. London: Fontana.

Oldroyd, D. R. (1986). The arch of knowledge. New York: Methuen.

Pais, A. (1982). Subtle is the lord: the science and the life of Albert Einstein. Oxford: Oxford University Press.

Pantin, C. F. A. (1968). The relations between the sciences. Cambridge: Cambridge University Press.

Pelto, P. J. \& Pelto, G. H. (1978). Anthropological research: The structure of inquiry. Cambridge: Cambridge University Press.

Peters, T. (1997). The circle of innovation. London: Hodder \& Stoughton.

Phillips, B. (1985). Sociological research methods. Burr Ridge, Illinois: Richard D. Irwin.

Pollard, H. R. (1974). Developments in management thought. London: William Heinemann.

Pollard, H. R. (1978). Further developments in management thought. London: William Heinemann.

Polya, G. (1954). Mathematics and plausible reasoning I: Induction and analogy in mathematics. Princeton, NJ: Princeton University Press.

Polya, G. (1957). How to solve it. Princeton, NJ: Princeton University Press.

Popper, K. (1978). The unity of method. In J. Bynner \& K. M. Stribley, Social research: Principles and procedures (pp. 17-24). London: Longman.

Popper, K. (1979). The logic of scientific discovery. New York: Basic Books.

Pratt, V. (1978). The philosophy of the social sciences. London: Methuen.

Riley, M. W. (1963). Sociological research. New York: Harcourt Brace.

Robertshaw, J. E., Mecca, J. S. \& Rerick, M. N. (1978). Problem solving: A systems approach. New York: Petrocelli.

Rosnow, R. \& Rosenthal, R. (1996). Beginning behavioral research. Englewood Cliffs, NJ: Prentice-Hall.

Rummel, J. F. (1964). An introduction to research procedures in education. New York: Harper \& Row.

Ruse, M. (1998). Taking Darwin seriously. Amherst, NY: Prometheus.

Ryan, A. (1970). Philosophy of the social sciences. New York: Macmillan.

Sanderson, J. B. (1994). Biological microtechnique. Oxford: Bios Scientific. 
Schoderbek, P. P., Schoderbek, C. G. \& Kefalas, A. G. (1990). Management systems: Conceptual considerations. Burr Ridge, Illinois: Richard D. Irwin.

Sekaran, U. (1992). Research methods for business. New York: John Wiley.

Siever, R. (1970). Science: Observational, experimental, historical. In D. C. Miller, Handbook of research design and social measurement (pp. 21-30). New York: David McKay.

Singer, C. (1959). A short history of scientific ideas to 1900. Oxford: Oxford University Press.

Singleton, R. A., Straits, B. C. \& Straits, M. M. (1993). Approaches to social research. Oxford: Oxford University Press.

Smith, R. (1997). The Fontana history of the human sciences. London: Fontana.

Sperber, I. (1990). Fashions in science. Minneapolis: University of Minnesota Press.

Terre Blanche, M. \& Durrheim, K. (1999). Research in practice: Applied methods for the social sciences. Cape Town: University of Cape Town Press.

Thouless, R. H. (1953). Straight and crooked thinking. London: Pan.

Timasheff, N. B. (1957). Cited in M. W. Riley, (1963). Sociological research (p. 27). New York: Harcourt Brace.

Toulmin, S. (1953). The philosophy of science. London: Hutchinson.

Troncale, L. (1988). The systems sciences: What are they? Are they one, or many? European Journal of Operational Research, 37, 8-33.

Tuckman, B. W. (1978). Conducting educational research. New York: Harcourt Brace Jovanovich.

Turney, B. \& Robb, G. (1971). Research in education. Hinsdale, Illinois: The Dryden Press.

Von Bertalanffy, L. (1968). General system theory. New York: George Braziller.

Wartofsky, M. W. (1979). Models. Boston Studies in the Philosophy of Science, 48. Dortrecht: D Reidel.

Whewell, W. (1860). Theory of scientific method. In R. E. Butts (Ed.), (1989), William Whewell: Theory of scientific method. Indianapolis: Hackett.

Whitley, R. (1984). The intellectual and social organization of the sciences. Oxford: Oxford University Press.

Williamson, J. B., Karp, D. A., Dalphin, J. R. \& Gray, P. S. (1982). The research craft: Introduction to social research methods. London: Little, Brown \& Co.

Wilson, B. (1990). Systems: Concepts, methodologies and applications. New York: John Wiley.

Wilson, E. O. (1998). Consilience: The unity of knowledge. New York: Alfred A Knopf.

Wuketits, F. M. (1990). Evolutionary epistemology and its implications for humankind. Albany, NY: State University of New York Press.

Zikmund R (2003). Business research methods. Mason, Ohio: South Western.

Ziman, J. (1978). Reliable knowledge. Cambridge: Cambridge University Press. 


\section{Biography}

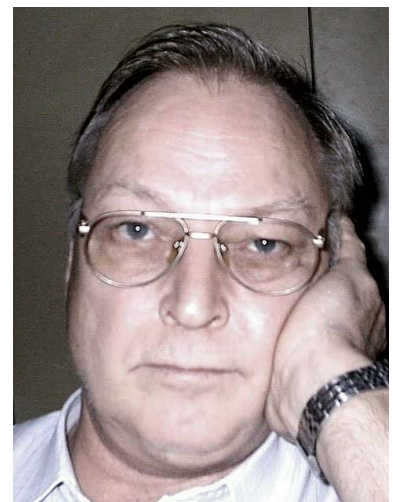

Jens Mende has a bachelor's degree in applied mathematics, a diploma in computer science, a master's in management, and fifteen years' practical experience, mainly in information system analysis, design and programming. He has spent the last twenty-five years at the University of the Witwatersrand, teaching programming, system design, IS management and report writing. He has published three dozen papers on computer education, system design and IS management, and has written another two dozen on logic, report writing, research method and evolution everywhere - which are currently in the process of publication. 